\title{
CHALLENGES AND CONSIDERATIONS OF THE NEW LABOR MARKET IN THE MEDIA INDUSTRY
}

\section{Retos y reflexiones sobre el nuevo mercado laboral en los medios de comunicación}

José-María Álvarez-Monzoncillo, Fernando Suárez-Billbao and Guillermo DeHaro

Nota: Este artículo puede leerse traducido al español en

http://www.elprofesionaldelainformacion.com/contenidos/2016/mar/13 esp.pdf

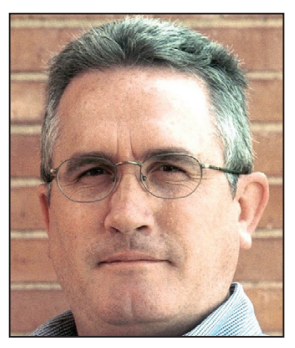

José-María Álvarez-Monzoncillo is professor of audiovisual communication and vice chancellor of continuing education, degrees, graduate studies, and international relations at Universidad Rey Juan Carlos (URJC). Director of the Master on television journalism (URJC-RTVE) and of the research group Infocent. Coordinator of the University master on film, television and interactive media. Author or coauthor of thirty-eight books and over thirty articles in scientific journals on the economy of communication, cultural industries, and information technology.

http://orcid.org/0000-0002-2009-7466

josemaria.alvarez@urjc.es

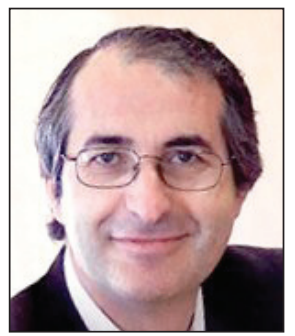

Fernando Suarez-Bilbao has a degree in geography and history and a doctorate in philosophy and letters from the Universidad Autónoma de Madrid. He graduated in law from the Universidad Complutense de Madrid and obtained a doctorate in law from the Universidad Rey Juan Carlos (URJC). Professor of history of law in URJC, he has been rector of this university since 2012. Author of numerous publications, both monographs and articles in professional journals. He is an academic of the Royal Academy of Jurisprudence and Legislation and the Real Academia of History, and full member of the Society for Medieval Studies since 1996.

http://orcid.org/0000-0003-1760-0144

fernando.suarez@urjc.es

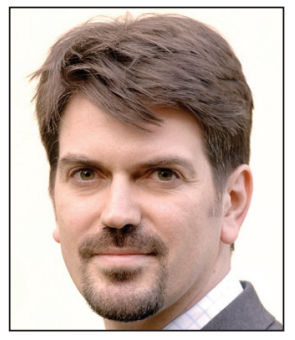

Guillermo De-Haro is professor of applied economics at the Universidad Rey Juan Carlos (URJC), telecommunications engineer, doctor of business organization, and doctor in economics. He has been director of strategic development at Technicolor Entertainment Services Spain and he is invited professor at New European College Munich and IE Business School. Author of books like "Corleone Business School" and publications such as "When a tail is not long enough." He is a partner of the digital publishing project JotDown.

http://orcid.org/0000-0002-2214-8060

guillermo.deharo@urjc.es

\section{Abstract}

Recent changes in the economic, social, and technological environment have impacted the careers of information professionals. On one hand, new jobs and opportunities have appeared, and on the other hand, layoffs in mainstream media companies indicate that the net impact has been negative. This article attempts to analyze the most important changes in the media environment, the main forces affecting supply and demand, and the impact of changes on the careers of information professionals. Finally, we propose that some of the new radical paradigms in the world of information professionals are not conceptually new.

\section{Keywords}

Media; Cultural industries; Crisis; Employment; Technology; Content; Creativity; Labor; Jobs. 


\section{Resumen}

Los recientes cambios en el entorno económico, social y tecnológico han supuesto un fuerte impacto en la carrera de los profesionales de la información. Mientras que por un lado aparecían oportunidades y nuevos puestos de trabajo, por otro lado los despidos en los principales medios hacían pensar que el resultado neto era negativo. Este artículo analiza los principales cambios en el entorno, las fuerzas más relevantes que afectan a oferta y demanda, así como su impacto en los profesionales de la información. Finalmente se plantea que algunos de los supuestos cambios de paradigma radicales en el mundo de los profesionales de la información no son conceptualmente tales.

\section{Palabras clave}

Medios de comunicación; Industrias culturales; Crisis; Empleo; Tecnología; Contenidos; Creatividad; Trabajo; Empleos.

Álvarez-Monzoncillo, José-María; Suárez-Bilbao, Fernando; De-Haro, Guillermo (2016). “Challenges and considerations of the new labor market in the media industry". El profesional de la información, v. 25, n. 2, pp. 262-271.

http://dx.doi.org/10.3145/epi.2016.mar.13

\section{Something new under the sun}

In 2008 the Lehman Brothers collapse marked the beginning of the so-called "great recession", a crisis that affected the labor market worldwide. The financial crisis accelerated the negative impact of technologies, like the Internet and mobile communication, on media practices.

Similar to the way the industrial revolution changed the labor market by making it necessary to have qualified personnel to operate machines for manufacture, today technology and the economy demand a new type of personnel. The current changes are in many cases common to all sectors and affect virtually every industry, including information professionals working in media.

Finally, perfect competitive markets, more efficient but with zero benefits by definition, are based on the existence of full information transparency or perfect and free information (Samuelson; Nordhaus, 2010). The emergence of the Internet is putting pressure on information industries to operate more efficiently with lower costs, causing a similar effect and thus reducing margins. This trend is putting intense pressure on the most information-rich industries, such as the media.

Perfect competitive markets, more efficient but with zero benefits by definition, are based on the existence of full information transparency

Like any disruptive technology, the Internet has displaced many employees over the past two decades, mainly from traditional and cultural industries (media, music, film, television, games, etc.). Initially this trend went unnoticed because consumption dramatically increased parallel to sustained economic growth. However, the eventual economic crisis accelerated the evolution of the Internet. As a result, digital content was left in the hands of advertising. In other words, income from sales decreased for all traditional industries, and revenues from advertising sales in the new digital market was insignificant. In the case of print media, advertising accounts for only $3.4 \%$ of total advertising investment, despite the fact that revenues have grown consis- tently worldwide in recent years. In Spain the fall in advertising investments in conventional media has not been offset by growth in advertising in digital media (Infoadex, 2014). The music and media industries have been impacted significantly by this situation.

\section{The fall in advertising investments in} conventional media has not been offset by growth in advertising in digital media

The impact of the Internet on the job market has been seen as a decoupling of productivity and technology, accentuated after the bubble crisis of technological companies in the early twenty-first century (Brynjolfsson; McAfee, 2011). Quoting Marc Andreessen, Netscape founder and investor in technology,

"The spread of computers and the Internet will put jobs in two categories: People who tell computers what to do, and people who are told by computers what to do".

This shift to a "digital economy" has caused changes in information and communication technologies (Tapscott, 1995) and has impacted all industries, especially companies within the cultural and media industries, as we said previously.

Commentators (Dutton; Imlah, 2013) have extended the concept of "information economy" (Bell, 1974), including Manuel Castells who introduced the idea of the "connected society", described as a society that combines networks, information, and infrastructure in such a way that impacts people. Other writers have (Mesenbourg, 2001) described the defining elements of the digital economy as infrastructure (hardware, software, networks, etc.), e-business (how companies are organized through computer networks), and e-commerce (selling products, physical or not, and services through networks). And others (Barbrook, 1997) describe the information economy as new technologies (computer networks) and new workers - the "digital craftsman" who molds a commodity: information.

Tapscott believes the digital economy solves the problem of the class struggle by transforming workers into knowled- 
ge workers, as Drucker had declared decades earlier and reaffirmed later (Drucker, 1959; 1999),

"The most valuable asset of a $21^{\text {st }}$-century institution (whether business or nonbusiness) will be its knowledge workers and their productivity".

However, the reality is

"The provision of free labor is a fundamental moment in the creation of value in the digital economies" (Terranova, 2000, p. 36).

The "gift economy" (Cheal, 1988) appears as a midpoint between culture DIY (do-it-yourself) and left-side free-market neoliberalism.

The problem of quantifying the value of knowledge makes it difficult to solve the dilemma of whether the Internet has created or destroyed the labor market. Terranova proposes the concept of immaterial labor (Lazzarato, 1996, p. 133; Gill; Pratt, 2008), which does not separate labor classes by activities in a post-industrial society. The immaterial labor concept is associated with a collective economy based on a collective intelligence (Levy, 1997) where the work is created and managed by a community of followers or readers. It is not necessarily free, but the return occurs in the form of social capital (Bourdieu, 1986).

Another result of Internet connectivity has been the convergence of isolated sectors. For example, in the past the music industry was separate from the computer industry; however, after Apple released iPods with iTunes the music and computer industries collapsed while Apple grew to become the largest company in the world. Later more companies entered the recording industry, historically a market with high entry barriers, ultimately eroding margins and pressuring incumbents. One consequence of convergence of the music and compute industry has been the interest in cultural and/or entertainment content that takes advantage of networks with high bandwidth, that previously were "empty". In addition, before the Internet, the music industry faced limitations and unmet demand because recordings had to be physically distributed; however, digital distribution has taken care of unmet demand with the famous longtail effect (Anderson, 2008). A specific impact is the "media convergence" (Dwyer, 2010) according to Meikle and Young (2011, p. 4) "converging media means to us media digitally interconnected." For these authors convergence means that the same content can circulate on radio, TV, press, social networks, etc.

The impact of the economic crisis, digital economy, convergence, and other factors on the information professional is difficult to quantify. No specific data are available and convergence of industries complicates the analysis. Nonetheless, Díaz-Nosty (2011, p. 62) created an estimate of employment among journalists in 2010 and found a marked tendency to

"substitute experienced journalists with other temporary, inexpensive, younger empoloyees."

Loss of experience in a knowledge economy is a negative. And, sadly, the concept of a lifelong professional career, associated with a permanent contract, is in decline. In the future "self-programmable labor" will be in demand (Castells, 1996; 2000). Employees will not have defined jobs, but will be involved in multiple projects. Informal employment will be the norm with more and more employees accessing the labor market, or remaining in it, through personal projects or as freelancers (Beck, 2000). This is already a reality, for example in the US more than a third of the workforce is freelance and is estimated to reach $40 \%$ by 2020 (Horowitz; Rosati, 2014). The report begins saying:

"Gone are the days of the traditional 9-to-5. We're entering a new era of work - project-based, independent, exciting, potentially risky, and rich with opportunities".

Adapting business models is necessary for the continued survival of journalism (Marcos-Recio; García-Alonso; Parra-Valcarce, 2014). However, Infoadex shows a drop in ad spending, from Euro 14,915 million in 2008 to Euro 10,461 in 2013 (2014 data, published in 2015). Newspapers have fallen from Euro 1,508 million to 663 in the same period.

\section{Informal employment will be the norm} with more and more employees accessing the labor market, or remaining in it, through personal projects or as freelancers

The previously cited authors mention business models that use subscriptions and paywalls, but these revenue applications have to be considered carefully, taking into account that subscriptions and paywalls reduce visits, thereby reducing revenue from advertising.

"Nobody is able to predict which and how many are the ways of financing print media. But change has to occur if they do not want to disappear" (Marcos-Recio; GarcíaAlonso; Parra-Valcarce, 2014).

The emergence of new competitors fighting for the attention of information consumers, such as social networks, makes clear the growing magnitude of the problem.

Internationalization could be key in the transition to digital European newspapers because traffic from consumers in other countries could increase by up to $20 \%$ in some cases (Peña-Fernández; Lazkano-Arrillaga; García-González, 2015). However, the revenue impact may be less than expected as advertising in newspapers has a strong local component.

A radical change in content and creation valuation has happened with web analytics (Schlesinger; Doyle, 2014). Today it is possible to know in real time who reads what news and to have a low-cost bidirectional channel for comments and reviews, which is much more efficient than letters to the editor. The speed of creation and consumption of content in the digital environment is causing rapid change. Schumpeter describes today's newspaper market as creative destruction, opening the doors to the concept of creator as entrepreneur (Siles, Boczkowski, 2014).

Finally, many of these factors are driven by digital natives (Prensky, 2001, p. 1) who demand random content, con- 
sume quickly, multitask, prefer work in an interconnected environment, and are driven by instant gratification. The millennial generation (Strauss; Howe, 1991, p. 377) also pursues "an excess of academic offerings that increases job insecurity" (Díaz-Nosty, 2011, p. 54). Because the continual driving Internet technology in Spain has been ADSL, we can define 2000 as a differential year. The first web server operated in 1993, therefore, digital born young adults (Spear, 2007) are now entering the workplace.

\section{All content (worth publishing)}

Through time there have been three main production systems: the plow, assembly chain, and computer (Toffler, 2006, p. 56). Historically, new jobs replace old jobs. Do these new jobs create or destroy employment? This question remains unanswered, but we do know that new job creation is linked to new and evolving abilities and professional skills. And, according to Toffler, more people are working, but remain unemployed. At first it appears to be a paradox, yet today journalism is without journalists, filmmakers are without producers, and musicians without record labels (Adecco, 2012).

\section{With social networking people's leisure time has become interactive and com- panies have altered their ways of wor- king, selling, and innovating}

There are new methods for generating income in the field of information and communication including co-creation, collaboration, participation, innovation, decentralization, outsourcing, and networking. These are not entirely new concepts, but the Internet has accelerated their use through two types of innovation: technology and social. As the world becomes more interconnected and intelligent, businesses today face a new era of social business. With social networking people's leisure time has become interactive and companies have altered their ways of working, selling, and innovating. It is the social business that is based on sharing information and knowledge. Everything is less vertical and the world becomes flat.

"Hierarchies are being flattened and value is being created less and less within vertical silos and more and more through horizontal collaboration within companies, between companies, and among individuals." (Friedman, 2005).

As the Internet has changed the market forever, integration of social computing into the enterprise represents another change of enormous importance. Organizations that are successful in transforming themselves into a social business can potentially reap significant benefits: the ability to deepen relationships with customers, to boost operational efficiency and to optimize the workforce. Three general trends make possible this transformation: 1) all is becoming instrumental with sensors and computing power; 2 ) the world is increasingly interconnected through vast ubiquitous networks; and 3) the application of analytical tools for an intelligent exploitation of the immense amount of data that can be collected.
During the era of Fordism, technology transformed the nature of work in order to increase productivity. For example, the use of robotics and intelligent devices allowed businesses to reduce routine processes in the assembly chain. A second wave of work redesign over the past two decades has affected the work involved in processing information and routine transactions (e.g., logistics). Now a third wave of change is coming to jobs, that involve complex interactions, deep knowledge, independence of judgment and experience. These are the jobs of the knowledge economy. A new stage with

"many murky corners of a vast constellation of interconnected issues: the power of distributed knowledge and open platforms, the profound transformations that they are bringing to market structures and business organizations, the necessary shifts in business strategy and worker skills in the new environment, and the barely recognized challenges facing governments in adapting to the new environment" (Bollier, 2011, p. 44).

It is therefore important to understand how this affects businesses and how they organize the work of their employees or collaborators. If it is true that this is the third industrial revolution, as proposed by Jeremy Rifkin (Rifkin, 2011), work organization and careers must change. The concept of creative industries was introduced by the government of Tony Blair as

"those industries which have their origin in individual creativity, skill and talent and which have a potential for wealth and job creation through the generation and exploitation of intellectual property" (DCMS, 1998, p. 3).

The concept was drifting towards the creative economy, and the class and the creative cities of Richard Florida, but has been criticized (Miller, 2004; 2012).

These new job fields are affected by the following processes / phenomena and trends:

- More "free luncheons" questioning private property and breaking with the idea that creativity and talent are individual:

"The definition stresses that creative activities have their origin in individual creativity, skill and talent. [...] the individual aspect represents a romantic, rather than realistic view. Artistic creation and knowledge development are supported by collective processes" (Smiers; Van Schjindel, 2008, p. 74).

All this theory must be understood in the logic of the hacker ethics.

- The development and cheapening of digital technologies has enabled the existence of the "weekend artist" that Negroponte named in the eighties. Many viewers also want to create content (movies, series, short films, documentaries, news, travel guides, gastronomy magazines, file sharing networks, voting systems vindicating a new political governance or representation, thousands of applications (apps) for smartphones, tablets, consoles...).

- More social and labor mobility in a new environment with new lifestyles that generate new social cleavages (communiteens, raised in the digital era and linked through social networks; silverpreneurs, for whom bringing their 
experience and professional knowledge to new projects is important; and the like).

- Prototyping is "an approach to developing testing and improving ideas at an early stage before large-scale resources are committed to implementation" (Nesta, 2013).

- A misinterpretation of the prosumers concept created in the eighties that has moved to the Internet. Although most of consumption is massive and most consumers express their disinterest in product customization, the term prosumers in the network refers to users that create, comment, collaborate, and distribute. Individualism in cultural consumption, especially in the audiovisual sector, and increasing choices, i.e., the ability to configure one's leisure and media diet.

- Thanks to the Internet, employers can make "virtual work" a reality. Therefore, where and when work is carried out changes in order to meet the needs of both employers and employees. Ubiquitous broadband connections and other technologies allow many jobs to be carried out online. This not only helps employees to choose working routines to suit their lifestyle preferences, but also gives employers unprecedented flexibility in how they use staff (McKinsey, 2012). Employers have access to employees who could not otherwise collaborate.

- This is the first time in history that technologies allow us to enjoy the benefits of large organizations (economies of scale or of knowledge) without having to forego the benefits of smaller companies (freedom, creativity, motivation, and flexibility) (Malone, 2004).

- Networking as a way to build social communities around work. Thanks to the Internet one can create virtual networks, especially social media, impossible in the physical world.

- Co-creation is the holy grail of information society. It refers to the phenomenon by which content can be generated by creating value (user-created content, user-generated content and user-distributed content). These concepts are associated with motivation and incentives for users to create, but without any profit or commercial interest (Benkler, 2006). The idea of co-creativity in the context of creative industries

"is based on the development of the explanatory model that focuses on the complex interactions between the market and the dominant culture" (Hartley et al., 2013, p. 23).

- Open and reverse innovation. Reverse innovation is the opposite of glocalization, where companies develop products at home and then fit the needs and budgets of customers in emerging markets (Oxford economics, 2011, p. 20). Open innovation, a term coined by Henry Chesbrough, is a new strategy in which companies show their lines of innovation and cooperate with external professionals. This kind of innovation responds to the possibility of occurrence of what is known as collective intelligence, kind of Wikipedia style.

- Introducing wikinomics into companies and organizations by establishing a context of self-organization (creating collaborative communities within companies), redefining the common good (sharing assets and resources), implementation of an open model, consolidation of a vanguard small team able to exercise leadership towards change, creating a collaborative culture or delegating power to the Net generation (Tapscott; Williams, 2010, pp 343-360).

- Information is a product of the digital era and the Internet is its transport vehicle. Oddly enough, the end result is more misinformation, because

"The wrong information can be transmitted just as easily as the right information" (Wurman, 2001, p. 13). Concepts like infoxication or toxic information, information explosion, and explosion of non-information have been used to describe this effect. Wurman goes further and considers that the information age is actually the age of data and non-information.

"To deal with the increasing onslaught of data, it is imperative to distinguish between the two; information is that which leads to understanding."

Moreover, following the reasoning, he presents a personal view about what each consumer considers data or information (Wurman, 2001, p. 19)

"Everyone needs a personal measure with which to define information. What constitutes information to one person may be data to another."

- It's an industry where the marginal cost of distributing, sharing, storing, or transforming information tends to zero (Fournier, 2014).

- It's an Information age where "credibility is the scarcest resource, the best propaganda is not propaganda" (Nye, 2012).

We cannot meet these challenges without a change in the way we work within cultural industries and information. Thanks to technological development, work is evolved into informal technology (domestic production, barter, and at its most extreme the black market and criminal economic activity).

\section{Markets are conversations}

The sentence "markets are conversations" was the thesis of Cluetrain Manifesto (Levine et al., 2001, p. xiv), which can be related directly to user generated content (UGC) production. We have to see this production differently from the traditional perspective:

"If the industrial era highlighted the values of discipline and hard work (in addition to the downward vertical flow of authority, the importance of financial capital, market functioning and relationships based on private property), the collaborative era is more related to creative play, P2P interactivity, social capital, participation in open commons and access to global networks" (Rifkin, 2011, p. 351).

The motivation and unpaid participation as mere pleasure is connected with the new social aspirations, personal fulfillment, and social influence (work / participation) in cultural production.

Meanwhile, the crisis and cannibalization of conventional media continues because of the Internet, creating a 
low-cost labor pool in a productive and shared leisure environment. This new "task" in the media and creative / cultural industries requires companies to be more open to collaboration and cooperation, and even to outsource innovation. These industries can combine the advantages of both small and large businesses, promote virtual work, and address a customer who decides for themselves the composition of their of leisure and information consumption, and thinking about the business in terms of "free" versus "pay" (Anderson, 2009). Social networks have caused a change:

"Peer to peer learning shifts the focus from the solitary self to the group. The learning is no longer an isolated experience between an authority figure and a student, and becomes a community experience" (Rifkin, 2011, p. 336).

It is one of the keys to competitiveness, but we must not fall into the innocence of forgetting the traditional ingredients of competitiveness. Almost all new learning skills are aimed at something trite enough and more fashionable than in the past: teamwork.

The new tools allow knowledge and innovation transfer among users and consumers. This flow also creates new problems. If in the past the high production costs fomented oligopolies of companies, it may be true that currently the reduction of production costs allows us to talk about the fulfilled dream of Ithiel de Sola Pool (1983) in Technologies of freedom resulting in the diversity and pluralism. Traditional companies are losing power because the Internet has removed their full control of the value chain. The degradation of power, including that of the press, involves five risks: disorder, loss of talent and knowledge, trivialization of social movements, impatience shortening attention spans, and alienation (Naím, 2013, pp. 332-338).

Disturbingly, there are new oligopolies and monopolies that do not produce content, instead they are parasitizing the incumbents (Álvarez-Monzoncillo, 2011). The brief history of Internet has shown that content is not king, but connectivity is. When the Internet emerged "content is king" was a saying that was said and written about frequently; however, we now know that communications providers (Viacom, Telefónica) have triumphed over entertainment companies and content producers (Warner, Disney, and Prisa).

We should not fall into the false notion that cultural production tools are essential: there are more important and transcendental things like talent and the ability to develop projects. In a movie script, the score of a song, or the bible, almost no technologies are involved. It is therefore very difficult to see how the boundaries between amateur and professional might disappear. Even distribution and marketing are often key in cultural industries. Trends and sales strategies are designed in different offices to places of creation.

User participation is proving to be a bit more complex than originally thought.

"There are issues to do with who participates, and how their access is enabled. There are competing views on whether those involved in a creative act or whether they are unwittingly donating their labour to a commercial interest or, indeed, whether they are doing both... The egalitarian, anti-corporate ethic, which drives much of the celebration of the political potential of web 2.0 sits uncomfortably with the fact that their enthusiasms are supporting interests that are, nonetheless, uncontestably, commercial" (Turner, 2010, p. 151).

It is true that there is great selfless production, but there are other motivations to be pursued in a multidisciplinary area that encompasses psychology. The voluntary creation poses some problems

"to succeed, users need to be motivated to contribute in the first place ('getting stuff in'). Further, given heterogeneity in content quality and variety, the degree of success will depend on incentives to contribute a desirable mix of quality and variety ('getting good stuff in'). Third, because UCC systems generally function as open access publishing platforms, there is a need to prevent or reduce the amount of negative value (polluting or manipulating) content" (Jian; Mackie-Mason, 2012, p. 423).

Another aspect associated with the Web is a certain goodness and righteousness, obtained from the supposed democratization of the medium, egalitarian, non-hierarchical, and the cool image (Gill, 2002). In this environment, work dynamism and informality are the main reasons of the mediums appeal (Gill; Dodd, 2000). But there also appear new forms of gender inequality framed in traditional existing patterns: in education, access to employment, and wages. Gill also relates to the main aspects valued by the media as "informality, autonomy, flexibility," among others. Generally, the same technology provokes contrary feelings and effects. On the one hand there is an isolation resulting from their use (for instance, a mobile phone makes us forget the people around us); on the other hand the same device allows "new forms of interactivity and participation" not only with other information consumers but also with the original producers of that information (Tyron, 2013).

There is an important digital divide based on knowledge and / or technological ignorance. Copyright or aspects such as security and privacy become vital but unknown in many cases. Sampedro suggests that "it is unclear whether future relations between hackers and media will be symbiotic or parasitic" (Sampedro, 2014, p. 188). Wikileaks put this debate on the table, which resulted in the purchase of raw data by the traditional media.

The production in cultural media, when viewed from the worker's perspective, is not free from external pressures and limitations (Deuze, 2007), but even so can be seen as a standardized work environment, controlled by a structure or organization of industrial type. Deuze insists that such activity should not be affected by the growing impact of prosumers and media users. He did not obviate the complexity and importance of the relations between agents (mediating payment or not), but considers these relationships "liquid", temporary, random, and unpredictable in what Lev Manovich defined as "remix culture" (Manovich, 2005) or the "lack of protection for authors" (Díaz-Noci; Tous, 2012). That is, the user-generated content exists within and outside commercial 
contexts, and both supports and attacks corporate control.

However, this user battalion produces content for organizations that do not realize the true potential of their staff and their peripheral environment.

"In the old model intelligence and creativity are not important, and management style of command and control has been very effective. But as organizations have decentralized, knowledge dominates markets and innovation becomes more important. To take advantage of people's intelligence and creativity has become an imperative for success" (Malone, 2004, p. 45).

"Command and control managers, with their rigid and strict rules give way to flexibility, collaboration and teamwork" (Toffler, 2006, p. 345).

Now managers are expected to be open, accessible, warm, convincing, and kind. This is why some authors say that there is a management "feminization", resulting in the need for skills like "soft power" to persuade with a "non-coercive" approach (Nye, 2004).

Terranova's statement that "working in the digital media industry is not as much fun as it is made out to be" (Terranova, 2000, p. 33), is based on examples of "volunteers" who

"used to work long hours and love it; now they are starting to feel the pain of being burned by digital media."

He points to the concept of "free labor" as a feature of the digital and cultural economy. This Marxist view of labor exploitation of content creators enthroned with key authors of the school of political economy in communication such as Mosco, Miège, Garnham, Murdock, Golding, etc. (Hesmondhalgh; Baker, 2013 and 2014). In general, it is confirmed that the creative work is a "nebulous concept" (Sanson, 2014).

\section{Conclusions}

Various factors alter the market for media. On the one hand there are changes in demand, both social and demographic, generational and cultural. On the other hand, technological changes based mostly on interactivity, customization, and low cost of the Internet along with the ubiquity of mobile devices and social media. Finally changes in markets, both in their basic mechanisms (information, access, legislation, etc.) and business models.

Changes in workplace processes and systems have always existed, but it is clear that the Internet has accelerated and changed the value chain of cultural and knowledge industries. The Internet has affected not only production (democratizing access to it), but also distribution and consumption. With the advent of the Internet, the dreamed interactivity between sender and receiver met some demands and enabled one to one marketing, and timidly increased market minorities or the long tail. This aspect of the network is crucial to understand the change that faces new information professionals, along with the importance of measuring the audience (quantitative) and even the sentiment (qualitative).
However, the process has the opposite effect. Many of the companies producing content see how their products are mixed with biased information, as it is the case of news and its influence on net neutrality. Today they compete with sources of information in real time like so-called "citizen journalism" and news agencies with channels like Twitter. The data are a commodity increasingly easy to obtain, so their processing is becoming essential. This causes the content providers to increasingly compete under the (subjective) opinion or analysis frameworks.

Finally, there is a lot of myth in relation to new processes and ways of working. In a time of radical change, like the current one, still we do not have enough perspective. We can guess that the new professional profiles will be related to the management of IT environments, knowledge of transmedia languages, and the ability to perform the entire process of collection, processing, and drafting of information.

We may be at an age where journalism gradually loses weight to give prominence to the information sciences. Yet always it will be necessary to have someone with credibility to process the data and deliver the news. It may be too early to assess the real extent of the processes and trends that are affecting new labor fields. Future discussions should include cultural factors of socio-cultural change, and to what extent technological transformations are only changes in demand without actually affecting content production. Also it might be interesting to discuss possible knowledge and digital gaps that are appearing in these new environments.

\section{Bibliography}

Adecco (2012). Futuros empleos: cómo trabajaremos en la Europa del futuro. Informe Adecco.

http://www.adecco.es/_data/NotasPrensa/pdf/401.pdf

Álvarez-Monzoncillo, José-María (2011). La televisión etiquetada. Madrid: Ariel/Fundación Telefónica. ISBN: 978 8408098706

Anderson, Chris (2008). The long tail: Why the future of business is selling less of more. New York: Hyperion Books. ISBN: 9781401309664

Anderson, Chris (2009). Free: The future of a radical price. New York: Hyperion Books. ISBN: 9781401322908

Barbrook, Richard (1997). "The digital economy: Commodities or gifts?". Subsol, 17 June.

http://subsol.c3.hu/subsol_2/contributors3/barbrooktext. html

Barbrook, Richard (1999)."The high-tech gift economy". In: Bosma, Josephine (ed.). Readme! Filtered by nettime: Ascii culture and the revenge of knowledge. Brooklyn, NY: Autonomedia, pp. 132-138. ISBN: 9781570270895

Barbrook, Richard; Schultz, Pit (1997). "The digital artisans manifesto by Richard Barbrook and Pit Schultz". The hypermedia research centre.

http://www.hrc.wmin.ac.uk/theory-digitalartisansmanifestoprint.html 
Bell, Daniel (1974). The coming of post-industrial society: A venture in social forecasting. London: Heinemann; originally published, New York: Basic Books. ISBN: 978 0465097135

Benkler, Yochai (2006). The wealth of networks: How social production transforms markets and freedom. New Haven: Yale University Press. ISBN: 9780300110562

http://www.benkler.org/Benkler_Wealth_Of_Networks.pdf

Bollier, David (2011). The future of work. What it means for individuals, businesses, markets and governments. Washington: The Aspen Institute. ISBN: 0898435439

http://www.aspeninstitute.org/sites/default/files/content/ docs/pubs/The_Future_of_Work.pdf

Bourdieu, Pierre (1986). "The forms of capital". In: Richardson, John (ed.). Handbook of theory and research for the sociology of education. New York: Greenwood, pp. 241-258. ISBN: 9780313235290

Brynjolfsson, Erik; Mcafee, Andrew (2012). “Jobs, productivity and the great decoupling". The New York times, 11 Dec. http://www.nytimes.com/2012/12/12/opinion/global/jobsproductivity-and-the-great-decoupling.html

Castells, Manuel (1996). The rise of the network society. The information age: Economy, society and culture. Oxford: Blackwell Publishers. ISBN: 978155786616

Cheal, David (1988). The gift economy. London: Routledge. ISBN: 9780415006415

DCMS (1998). "Creative industries mapping documents". Gov. UK. London: Department for Culture, Media and Sport. https://www.gov.uk/government/publications/creativeindustries-mapping-documents-1998

De-Sola-Pool, Ithiel (1983). Technologies of freedom. BeIknap Press Series. Harvard University Press, 299 pp. ISBN: 9780674872332

Deuze, Mark (2007). Media work: Digital media and society series. Cambridge: Polity Press. ISBN: 9780745639246

Díaz-Noci, Javier; Tous-Rovirosa, Ana (2012). “La audiencia como autor: narrativas transmedia y propiedad intelectual del público. Algunas reflexiones jurídicas". El profesional de la información, v. 21, n. 5, pp. 458-467.

http://dx.doi.org/10.3145/epi.2012.sep.03

Díaz-Nosty, Bernardo (2011). "Libro negro del periodismo en España". Madrid: Asociación de la Prensa de Madrid. ISBN: 9788487651473

http://www.apmadrid.es/images/stories/Libronegro1soloPDF_ BAJA.pdf

Drucker, Peter-Ferdinand (1959). The landmarks of tomorrow. New York: Harper. ASIN: B0006AVMNI

Drucker, Peter-Ferdinand (1999). Management challenges for the $21^{\text {st }}$ century. New York: Harper Collins. ISBN: 0887309984

Dutton, Bill; Imlah, Bill (2013). "The concept of a 'digital economy'". Oxford Digital Economy Collaboration Group. Fostering collaboration with the digital, Internet, and creative industries. http://odec.org.uk/2013/09/02/the-concept-of-a-digitaleconomy

Dwyer, Tim (2010). Media convergence (issues in cultural and media studies). Berkshire: Open University Press. ISBN: 9780335228737

Friedman, Thomas (2005). The world is flat: A brief history of the twenty-first century. New York: Farrar, Straus and Giroux. ISBN: 9780312425074

Fournier, Laurent (2014). Merchant sharing: Towards a zero marginal cost economy. Cornell University Library. http://arxiv.org/pdf/1405.2051.pdf

Freelancers Union \& Elance-o Desk (no date). Freelancing in America: A national survey of the new workforce.

https://fu-web-storage-prod.s3.amazonaws.com/content/ filer_public/7c/45/7c457488-0740-4bc4-ae45-0aa60daac531/ freelancinginamerica_report.pdf

Gill, Rosalind (2002). “Cool, creative and egalitarian?: exploring gender in project-based new media work in Europe". Information, communication and society, v. 5, n. 1, pp. 70-89. http://eprints.Ise.ac.uk/2446

Gill, Rosalind; Dodd, Dianne (2000). New media: Working practices in the electronic arts. Final report submitted to Directorate General V (DGV), European Commission, Brussels.

Gill, Rosalind; Pratt, Andy (2008). "In the social factory? Immaterial labour, precariousness and cultural work". Theory, culture \& society, v. 25, n. 7-8, pp. 1-30.

http://dx.doi.org/10.1177/0263276408097794

Hartley, John; Potts, Jason D.; Cunningham, Stuart D.; Flew, Terry; Keane, Michael; Banks, John (2013). Key concepts in creative industries. London: Sage. ISBN: 978 1446202883

Hesmondhalgh, David; Baker, Sarah (2013). Creative labour: Media work in three cultural industries. London: Routledge. ISBN: 9780415677738

Hesmondhalgh, David; Baker, Sarah (2014). "Toward a political economy of labor in the media industries". In: Wastko, Janet; Murdock, Graham; Sousa, Helena. The handbook of political economy of communications. Malden: Wiley Blackwell, pp. 381-400. ISBN: 9781118799444

Horowitz, Sara; Rosati, Fabio (2014) "53 million Americans are freelancing, new survey finds". Freelancers broadcasting network, 4 Sept.

https://www.freelancersunion.org/blog/dispatches/2014/0 9/04/53million/

Infoadex (2015). Estudio Infoadex de la inversión publicitaria en España 2014.

http://www.infoadex.es/resumen_estudio_2014.pdf

Jian, Lian; Mackie-Mason, Jeffrey K. (2012). “Incentivecentered design for user-contributed content". In: Peitz, Martin; Waldfogel, Joel. The Oxford handbook of the digital economy, pp. 399-433. Oxford: Oxford University Press. http://dx.doi.org/10.1093/oxfordhb/9780195397840.001.0001 
Lazzarato, Maurizio (1996). "Immaterial labor". In: Makdisi, Saree; Casarino, Cesare; Karl, Rebecca E. (eds.). Marxism beyond marxism. London: Routledge. ISBN: 978 0415914437

Levine, Rick; Locke, Christopher; Searls, Doc; Weinberger, David (2001). The cluetrain manifesto. New York: Basic Books. ISBN: 9780738204314

Lévy, Pierre (1997). Collective intelligence. Cambridge: Plenum/Harper Collins. ISBN: 9780738202617

Malone, Thomas W. (2004). The future of work: How the new order of business will shape your organization. Your management style, and your life. Boston: Harvard Business School Press. ISBN: 9781591391258

Marcos-Recio, Juan-Carlos; García-Alonso, Pedro; ParraValcarce, David (2014). "La actividad informativa en los medios digitales: ¿sobrevivirán los periódicos impresos sin publicidad?". Estudios sobre el mensaje periodístico, v. 20, n. 1, pp. 177-194.

http://dx.doi.org/10.5209/rev_ESMP.2014.v20.n1.45226

McKinsey Global Institute (2012). "Help wanted: The future of work in advanced economies". McKinsey \& Company, March.

http://www.mckinsey.com/insights/employment_and_ growth/future_of_work_in_advanced_economies

Meikle, Graham; Young, Sherman (2011). Media convergence. Networked digital media in everyday life. London: Palgrave McMillan. ISBN: 9780230228948

Mesenbourg, Thomas L. (2001). Measuring the digital economy. U.S. Bureau of the Census.

https://www.census.gov/econ/estats/papers/umdigital.pdf

Miller, Toby (2004). "A view from a fossil: The new economy, creativity and consumption two or three things I don't believe". International journal of cultural studies, v. 7, n. 1, pp. 55-65.

http://spartan.ac.brocku.ca/ tkennedy/COMM/Miller2004.pdf http://dx.doi.org/10.1177/1367877904040605

Miller, Toby (2012). Blow up the humanities. Philadelphia: Temple University Press. ISBN: 9781439909836

Naím, Moisés (2013). El fin del poder. Madrid: Debate. ISBN: 9788499923000

Nesta (2013). Prototyping framework: a guide to prototyping new ideas.

http://www.nesta.org.uk/publications/prototyping-framework

Nye Jr., Joseph S. (2004). Power in the global information age: from realism to globalization. London: Routledge. ISBN: 9780415700177

Nye Jr., Joseph S. (2012). "China's soft power deficit". The Wall Street journal, 8 May.

http://www.wsj.com/articles/SB100014240527023044511 04577389923098678842

Oxford economics (2011). The new digital economy: How it will transform business. http://myclouddoor.com/www/wp-content/uploads/ Whitepapers/The-New-Digital-Economy.pdf

Peitz, Martin; Waldfogel, Joel (eds.) (2012). The Oxford handbook of the digital economy. Oxford: Oxford University Press. ISBN: 9780195397840

Peña-Fernández, Simón; Lazkano-Arrillaga, Iñaki; GarcíaGonzález, Daniel (2016). "La transición digital de los diarios europeos: nuevos productos y nuevas audiencias". Comunicar, n. 46.

http://dx.doi.org/10.3916/C46-2016-03

Prensky, Marc (2001). "Digital natives, digital immigrants". On the horizon, MCB University Press, v. 9, n. 5, pp 1-6. https://edorigami.wikispaces.com/file/view/PRENSKY+-+DI GITAL+NATIVES+AND+IMMIGRANTS+1.PDF

Rifkin, Jeremy (2011). La tercera revolución industrial. Barcelona: Paidós. ISBN: 9788449326035

Sampedro, Víctor (2014). El cuarto poder en Red. Por un periodismo (de código) libre. Barcelona: Icaria. ISBN: 978 8498885903

Samuelson, Paul A.; Nordhaus, William D. (2010). Economics (19 ${ }^{\text {th }}$ ed.). Boston: McGrawHill Education. ISBN: 978 0073511290

Sanson, Kevin (2014). "Corresponding geographies remapping work and workplace in the age of digital media". Television \& new media, v. 16, n. 8, pp. 751-768.

http://dx.doi.org/10.1177/1527476414559289

Schlesinger, Philip; Doyle, Gillian (2014). "From organizational crisis to multi-platform salvation? Creative destruction and the recomposition of news media". Journalism: Theory, practice and criticism.

http://dx.doi.org/10.1177/1464884914530223

Siles, Ignacio; Boczkowski, Pablo (2012). "Making sense of the newspaper crisis: A critical assessment of existing research and an agenda for future work". New media and society, v. 14, n. 8 , pp. 1375-1394.

http://dx.doi.org/10.1177/1461444812455148

Smiers, Joost; Van-Schjindel, Marieke (2008). Imagine... No copyright. Barcelona: Gedisa. ISBN: 9788497844659

Spear, Josh (2007). "Wanna go to digital rehab? No No No: Talking to the born digital generation". Internet advertising bureau UK, 18 Nov.

http://www.iabuk.net/news/born-digtal-generation

Strauss, William; Howe, Neil (1991). Generations: The history of America's future, 1584 to 2069. New York: Harper Collins. ISBN: 9780688119126

Tapscott, Don (1997). The digital economy: Promise and peril in the age of networked intelligence. USA: McGraw-Hill Education. ISBN: 9780070633421

Tapscott, Don (2014). The digital economy. Rethinking promise and peril in the age of networked intelligence (Aniversary ed.). USA: McGraw-Hill Education. ISBN: 978 0071835558

Tapscott, Don; Williams, Anthony D. (2010). Macrowikin- 
omics. Reboting bussiness and the world. New York: Portfolio/ Penguin. ISBN: 9788950931469

Terranova, Tiziana (2000). "Free labor: producing culture for the digital economy". Social text 63, v. 18, n. 2, pp. 33-58. http://web.mit.edu/schock/www/docs/18.2terranova.pdf

Toffler, Alvin; Toffler, Heidi (2006). La revolución de la riqueza. Barcelona: Debate. ISBN: 9788483066744

Turner, Graeme (2010). Ordinary people and the media.
The domotic turn. London: Sage Publications Ltd. ISBN: 978 1848601673

http://dx.doi.org/10.4135/9781446269565

Tyron, Chuck (2013). On-demand culture: Digital delivery and the future of movies. NJ: Rutgers University Press. ISBN: 9780813561097

Wurman, Richard S. (2001). Information anxiety 2. Indianapolis: Hayden/Que. ISBN: 9780789724106

\section{Nueva colección EPI Scholar}

\section{Libros académicos y científicos de Información y Documentación}

\section{SEO. Introducción a la disciplina del posicionamiento en buscadores Jorge Serrano-Cobos}

¿EI SEO es fácil? ¿Difícil? Todo depende. Este libro aporta pistas para desarrollar una estrategia de acciones tácticas que lleven a un posicionamiento estable y ético desde cero en los motores de búsqueda de Internet, sin miedo a los cambios del algoritmo, para aquellos que no saben o que necesitan entender de optimización y posicionamiento en buscadores para coordinarse con otros profesionales.

Serrano-Cobos, Jorge (2015). SEO. Introducción a la disciplina del posicionamiento en buscadores. Barcelona: El profesional de la información, Editorial UOC, colección EPI Scholar n. 3, 202 pp. ISBN: 9788490649565

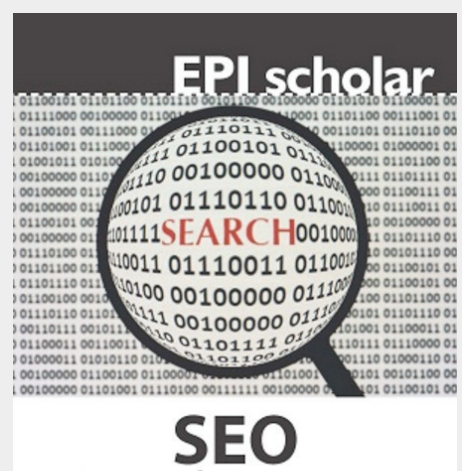

INTRODUCCIÓN A LA DISCIPLINA DEL POSICIONAMIENTO EN BUSCADORES JORTE SERTRANO-COBOS

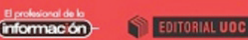

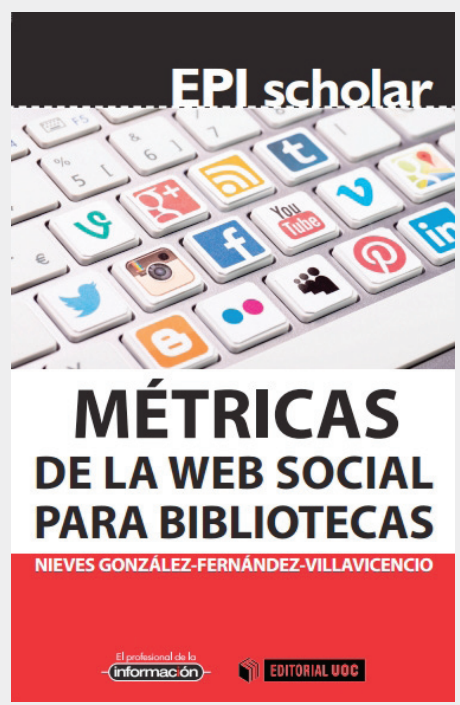

\section{Métricas de la web social para bibliotecas de Nieves González-Fernández-Villavicencio}

"Métricas de la web social para bibliotecas" identifica, describe y analiza los indicadores que no deben faltar en cualquier biblioteca en su plan de marketing digital y en la evaluación de su uso de los medios sociales, incluso para compararse con la competencia o entre iguales.

La rentabilidad de las acciones que llevan a cabo las bibliotecas en la web social se demuestra con métricas de impacto. Este libro señala cómo los medios sociales son buenos para conseguir beneficios ROI (económicos), pero sobre todo son muy buenos para conseguir beneficios no ROI: prestigio, reconocimiento, participación e interacción con los usuarios

González-Fernández-Villavicencio (2015). Métricas de la web social para bibliotecas. Barcelona: El profesional de la información, Editorial UOC, colección EPI Scholar n. 4, 282 pp. ISBN: 9788491161813

Información: Isabel Olea

epi.iolea@gmail.com

http://www.elprofesionaldelainformacion.com/librosEPIScholar.htmI 